\title{
PEMETAAN KELAYAKAN LAHAN UNTUK PENGEMBANGAN USAHA BUDI DAYA LAUT DENGAN APLIKASI INDERAJA DAN SISTEM INFORMASI GEOGRAFIS DI PERAIRAN LEMITO, PROVINSI GORONTALO
}

\author{
I Nyoman Radiarta, Adang Saputra, dan Ofri Johan
}

\begin{abstract}
ABSTRAK
Bagi kegiatan perikanan budi daya yang berkelanjutan, penentuan kualitas lingkungan yang memiliki risiko penurunan yang kecil sangatlah penting. Pemilihan lokasi yang tepat merupakan langkah penting untuk memastikan keberlangsungan kegiatan budi daya yang berkelanjutan. Lokasi yang jelek akan menimbulkan kegiatan usaha yang tidak berkelanjutan. Penelitian kelayakan lahan usaha budi daya laut telah dilaksanakan di perairan Lemito, Kabupaten Pohuwato, Provinsi Gorontalo pada bulan Agustus 2003. Tujuan dari penelitian ini adalah melakukan analisis kelayakan lahan budi daya laut dengan memanfaatkan data inderaja dan Sistem Informasi Geografis (SIG). Penentuan stasiun pengamatan dilakukan secara acak dengan teknik sistematik. Metode PATTERN dan SIG digunakan untuk menganalisis data lapangan (kualitas air: fisik, kimia, dan logam berat) dan data inderaja (Landsat ETM+). Hasil survai dan analisis laboratorium menunjukkan bahwa kondisi kualitas perairan (fisik, kimia dan logam berat) masih dalam kisaran yang baik. Total luasan daerah penelitian di perairan Lemito adalah 12.947 ha Berdasarkan hasil analisis SIG diperoleh lahan pengembangan kawasan budi daya yang sangat layak untuk keramba jaring apung (KJA) seluas 342 ha, budi daya rumput laut seluas 1.005 ha, dan budi daya kerang mutiara seluas 233 ha.
\end{abstract}

ABSTRACT: Area suitability mapping for mariculture development using application remote sensing data and Geographic Information System in Lemito coastal area, Gorontalo Province. By: I Nyoman Radiarta, Adang Saputra, and Ofri Johan

For the sustainability of aquaculture enterprise, it is important to select suitable area with low price at environmental degradation. Site selection is the first and generally most critical step in establishing sustainable aquaculture. Poor site selection can lead to failure. Research on area suitability mapping for mariculture development had been carried out at Lemito coastal area, Gorontalo Province on August 2003. The aim of this research is to analyze the suitability of area for mariculture using remote sensing and geographic information system (GIS). Simple systematic random sampling was used to allocate sampling points. PATTERN method and GIS have been used to analyze field data (water quality) and remote sensing data (Landsat ETM+). Based on the survey and laboratory analyzes, range of the water quality generally is still good for mariculture activities. Total research area in Lemito coastal area is 12,947 ha. Based on scoring and GIS analysis, the most suitable area for KJA, seaweed culture and pearl culture were found 342 ha: 1,005 ha; and 233 ha respectively.

KEYWORDS: $\quad$ mariculture, area suitability, remote sensing, GIS, Lemito

\section{PENDAHULUAN}

Perikanan budi daya, seperti kegiatan produksi lainnya memanfaatkan ketersediaan sumber daya alam, yang tergantung dari beberapa masukan di antaranya air, benih, dan makanan serta proses yang ada yang meliputi kemampuan lingkungan untuk menurunkan efek limbah untuk menghasilkan produk akhir berupa ikan, kerang, udang, dan mutiara bagi konsumen. Interaksi kegiatan ini dengan lingkungan akan menimbulkan keuntungan dari aspek sosial, ekonomi, dan lingkungan yang meliputi: penyediaan bahan makanan (sea food), penyerapan tenaga kerja, peningkatan pendapatan, peningkatan kesehatan, dan menurunkan tekanan terhadap sumber daya ikan akibat intensitas penangkapan yang tinggi (Beveridge, 1996; Ramelan, 1998). Di pihak lain, interaksi dengan lingkungan juga dapat menimbulkan efek negatif. Dengan makin banyaknya kegiatan budi daya laut yang tidak diatur dengan baik, maka limbah yang akan masuk ke dalam lingkungan perairan menjadi tidak terkontrol dan kegiatan budi daya tidak dapat 
berkelanjutan. Sehubungan dengan hal tersebut, untuk memastikan keberlanjutan kegiatan budi daya laut, maka data dan informasi tentang kelayakan lahan (site suitability) sangatlah diperlukan untuk memecahkan kompetisi dalam pemanfaatan pesisir dan menghindari penurunan kondisi lingkungan.

Undang-Undang No. 38/2000 telah menetapkan Gorontalo sebagai provinsi baru, yang merupakan pemekaran dari Provinsi Sulawesi Utara (Anonim, 2002a). Sesuai dengan nafas otonomi daerah dengan diberlakukannya Undang-Undang No. 22/1999 tentang Pemerintahan Daerah, maka provinsi ini harus mampu merencanakan, melaksanakan, dan mengelola pembangunannya secara mandiri. Dalam rangka pemanfaatan wilayah pantai dan laut, melalui undangundang ini pemerintah daerah diberikan pula kewenangan di wilayah laut yaitu 12 mil untuk Pemerintah Provinsi dan sepertiganya untuk Pemerintah Kabupaten/Kota. Kewenangan yang dimiliki daerah ini merupakan modal awal untuk melaksanakan pengelolaan secara terpadu. Provinsi Gorontalo yang memiliki luas laut 50.500 km² dengan panjang garis pantai $590 \mathrm{~km}$, mempunyai potensi lahan perikanan budi daya yang cukup besar (mencapai 16.675 ha), di antaranya budi daya laut yang meliputi rumput laut 2.450 ha, ikan 1.050 ha, dan mutiara 1.500 ha (Anonim, 2002a). Potensi yang dimiliki ini merupakan daya dukung potensial bagi pengembangan sumber daya hayati pantai dan laut.

Kabupaten Pohuwato merupakan pemekaran dari Kabupaten Boalemo yang dilakukan pada tahun 2001. Secara administratif kabupaten ini terbagi atas lima kecamatan yaitu: Kecamatan Paguat, Marisa, Randangan, Lemito, dan Popayato (Anonim, 2002b). Secara geografis kabupaten ini terletak di antara $121^{\circ} 07^{\prime}-122^{\circ} 09^{\prime}$ Bujur Timur dan $0^{\circ} 22^{\prime}-01^{\circ} 01^{\prime}$ Lintang Utara, yang masuk dalam kawasan pengelolaan Teluk Tomini. Banyaknya pulau-pulau kecil di sekitar perairan kabupaten ini merupakan lokasi yang potensial bagi pengembangan budi daya laut. Berdasarkan analisis Dinas Perikanan dan Kelautan Kabupaten Boalemo (setelah dimekarkan kabupaten ini menjadi dua yaitu Kabupaten Boalemo dan Pohuwato) menyebutkan bahwa Kabupaten Pohuwato mempunyai potensi budi daya laut yang cukup besar mencapai 1.450 ha, satu di antaranya terletak di Kecamatan Lemito/Popayato. Potensi yang dimiliki Kecamatan Lemito ini sebagian kecil telah dimanfaatkan baik oleh masyarakat setempat maupun oleh pengusaha.

Menurut Ismail et al. (2002), tidak seluruh perairan pantai cocok untuk usaha budi daya laut, untuk itu beberapa persyaratan yang meliputi persyaratan teknis, biologis, dan non teknis (sosial ekonomi dan budaya) harus diperhatikan. Data yang berhubungan dengan persyaratan tersebut harus dapat dikelola dengan baik, sehingga dapat memberikan hasil analisis yang maksimal. Sejak banyaknya data dan informasi ini dalam bentuk spasial, Sistem Informasi Geografis (SIG) merupakan aplikasi yang sangat relevan dalam melakukan analisis ini.

SIG khususnya digunakan untuk manajemen sumber daya alam dan pada tingkatan yang sederhana dapat digunakan sebagai manajemen data. Berbagai sumber data dan tipe yang berbeda dapat digunakan secara simultan dalam SIG yang mana keluaran yang dihasilkan umumnya sangat baik. Keunggulan dari SIG adalah mempunyai kemampuan dalam menggambarkan secara bersamaan berbagai faktor yang kompleks yang dilakukan dengan sistem tumpang susun (overlay). SIG mempunyai beberapa keunggulan dalam aplikasinya di bidang perikanan budi daya. Hal ini tidak hanya menampilkan karakteristik lingkungan yang meliputi kondisi fisik, biologi, dan sosial ekonomi, namun juga dapat melakukan analisis, sehingga dapat menyederhanakan permasalahan dan pemanfaatan waktu yang lebih efisien. Meskipun demikian, pemanfaatan SIG dalam bidang perikanan budi daya masih sangat terbatas. Ada beberapa hal penyebab keterbatasan pemanfaatan SIG ini (Nath et al., 2000 dalam Perez et al., 2003) di antaranya: (1) kurang dirasakan adanya keuntungan sistem ini dalam bidang perikanan budi daya, (2) terbatasnya pengetahuan akan dasar-dasar SIG dan metodologinya, (3) kurang adanya dukungan untuk keberlanjutan SIG antar organisasi, dan (4) lemahnya interaksi antar pengguna SIG. Pemanfaatan SIG dalam bidang perikanan budi daya pertama kali dimulai pada tahun 1980-an (Kapetsky et al., 1987). Pada saat ini, pemanfaatan data inderaja (Landsat TM, Landsat ETM+, SPOT, IKONOS) dirasakan sangat membantu dalam melakukan analisis SIG terutama untuk memberikan hasil analisis terkini. Data inderaja yang diintegrasikan dengan SIG akan membentuk data base yang dapat menunjang kebutuhan pengelolaan wilayah pesisir dan lautan, khususnya untuk penyusunan tata ruang wilayah pesisir. Untuk bidang perikanan budi daya khususnya budi daya laut pemanfaatan aplikasi ini dirasakan masih sangat kurang

Tujuan penelitian ini adalah melakukan analisis kelayakan lahan yang diperuntukkan bagi pengembangan budi daya laut, terutama bagi kegiatan budi daya ikan dalam keramba jaring apung, rumput laut, dan kerang mutiara dengan memanfaatkan teknologi SIG dan data inderaja (Landsat ETM+). Hasil dari penelitian ini diharapkan menjadi masukan bagi pemerintah daerah untuk mengalokasikan pengembangan budi daya laut dan sebagai bahan penyusunan rencana tata ruang wilayah. 


\section{BAHAN DAN METODE}

Penelitian ini telah dilakukan pada bulan Agustus 2003, dengan mengambil lokasi di sekitar perairan Kecamatan Lemito yang terbentang dari 121 ${ }^{\circ} 30^{\prime}-$ $121^{\circ} 46^{\prime}$ Bujur Timur dan $0^{\circ} 26^{\prime}-0^{\circ} 34^{\prime}$ Lintang Utara. Total luasan daerah penelitian adalah 12.947 ha. Berdasarkan kajian Pusat Kajian Sumber Daya Pesisir dan Laut-Institut Pertanian Bogor (PKSPL-IPB, 2002) yang diperkuat dengan adanya rencana tata ruang wilayah Kabupaten Boalemo (Anonim, 2002b) dan Gorontalo (Anonim, 2002a), perairan ini telah ditetapkan sebagai kawasan pengembangan perikanan budi daya laut. $\mathrm{Hal}$ ini sangatlah beralasan, karena banyaknya pulau-pulau kecil di sekitar perairan yang membuat perairan ini relatif tenang dan terlindung.

Metode yang dipakai dalam penelitian ini adalah metode survai yang dirancang berdasarkan SIG, Systematic random sampling (Clark \& Hosking, 1986; Morain, 1999) merupakan teknik yang digunakan untuk penentuan titik pengamatan, dengan jarak antara titik pengamatan $1,5 \mathrm{~km}$. Posisi sampling telah ditentukan sebelum survai ke lapangan. Global Positioning Sys- tem (GPS) dalam systematic random sampling berfungsi sebagai tracking data di lapangan. Pengambilan sampel kualitas air dilakukan pada pukul 08.30 WITA sampai dengan 17.30 WITA. Pengamatan kualitas perairan dilakukan di 39 titik pengamatan, sedangkan sampel air dan tanah untuk dianalisis di laboratorium diambil dari 10 titik pengamatan. Sebaran titik sampling dan ekosistem di lokasi penelitian dapat dilihat pada Gambar 1.

Data yang dikumpulkan dalam penelitian ini terdiri atas data primer dan data sekunder. Data primer yang dikumpulkan adalah data kualitas perairan yang meliputi: parameter fisik (luasan, kedalaman, suhu air, kecerahan, tinggi gelombang, kecepatan arus), kimia (salinitas, $\mathrm{pH}, \mathrm{DO}$, fosfat, nitrat, nitrit, amonia), logam berat (kadmium $(\mathrm{Cd})$, seng $(\mathrm{Zn})$, timbal $(\mathrm{Pb})$, tembaga (Cu)), dan kualitas sedimen (tekstur) serta data jenis dan kelimpahan plankton. Data sekunder berupa peta dasar lokasi penelitian. Peta dasar ini bersumber dari hasil digitasi citra satelit Landsat ETM+ (aquisisi 21 Juni 2001) path 114/row 060 keluaran LAPAN dan Bappedal, peta rupa bumi skala 1:50.000 (lembar: 2216-13, 2216-14, 2216-34, 2216-

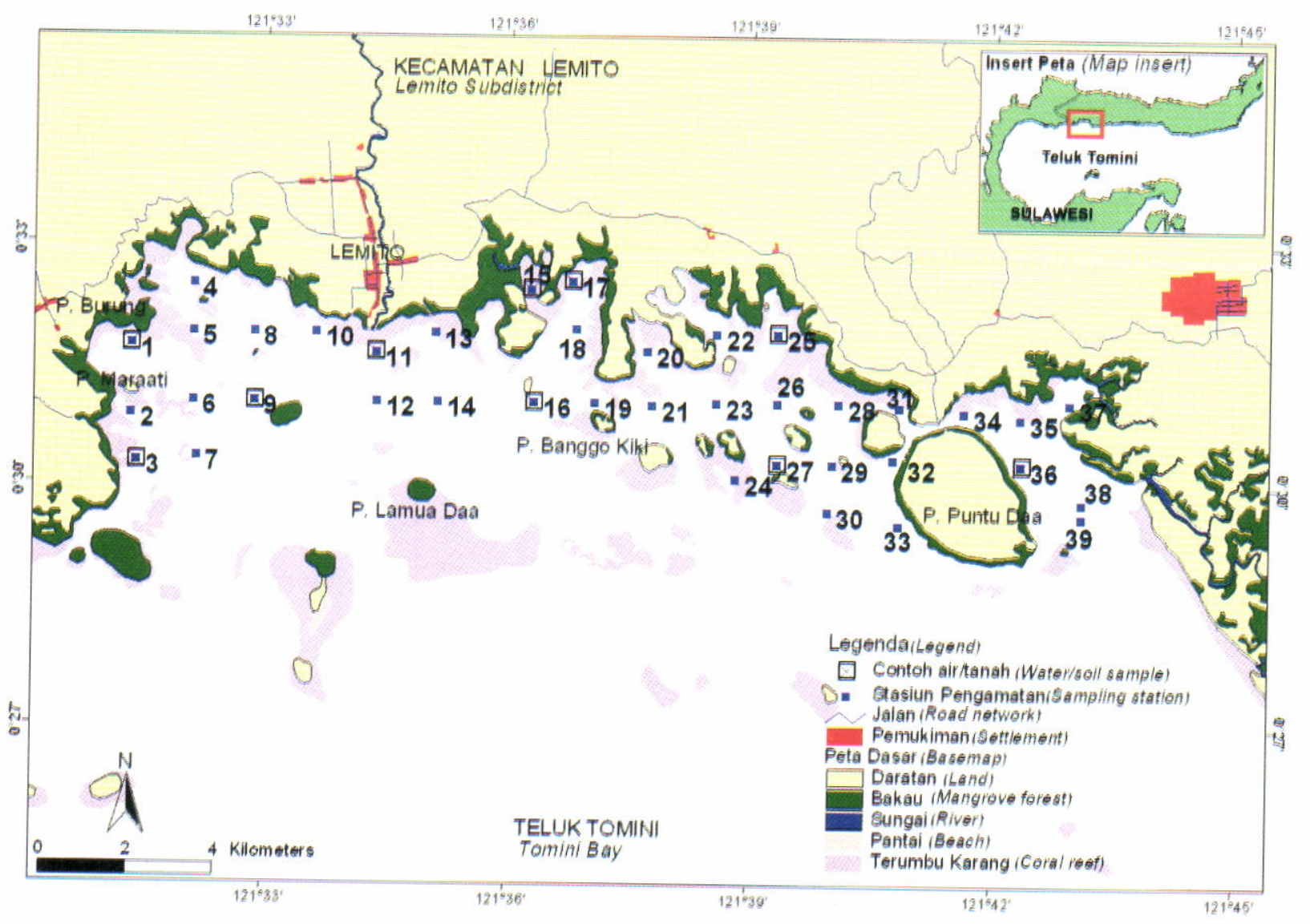

Gambar 1. Tampilan umum lokasi penelitian di perairan Lemito dan distribusi lokasi titik pengamatan kualitas perairan

Figure 1. General features of research location at Lemito and distribution of water quality sampling points 
41, 2216-42, 2216-62) tahun 1989 keluaran Bakosurtanal dan peta batimetri keluaran Dinas Hidro Oseanografi. Tema utama dari peta dasar yang diambil meliputi: garis pantai, mangrove, terumbu karang, lumpur (sedimentasi), sungai, jalan, sebaran penduduk, dan kedalaman perairan.

Evaluasi kelayakan lahan dilakukan dengan metode PATTERN (Planning Assisstance Through Technical Evaluation of Relevant Numbers) yang diterapkan untuk memecahkan masalah melalui pengambilan skor pada setiap kategori di setiap faktor dari informasi geografi (Bakosurtanal, 1995 dalam Saefuddin et al., 1996). PATTERN adalah metode untuk menghitung tingkat relatif dari kontribusi untuk setiap faktor lahan geografis untuk sampai pada tujuan akhir. Faktorfaktor lahan geografis diberikan pada bentuk peta-peta tematik, dan tujuan akhir adalah kelayakan lahan untuk budi daya laut. Pada metode ini setiap kategori di setiap faktor ditentukan dengan angka skor, dan total skor dihitung sebagai jumlah pembobotan dari setiap skor kategori. Bobot ditentukan melalui ketergantungan dari setiap faktor yang dikaitkan dengan tujuan.

Data kualitas perairan yang dikumpulkan berasal dari titik-titik pengamatan yang penyebarannya mewakili lokasi penelitian. Untuk menganalisis secara spasial, titik-titik tersebut terlebih dahulu dilakukan interpolasi, yang merupakan suatu metode pengolahan data titik menjadi area (polygon). Cara interpolasi titik menjadi area menggunakan metode Nearest Neighbor (Burrough \& McDonnell, 1998; Morain, 1999). Dari hasil interpolasi masing-masing parameter kualitas perairan yang diperoleh, disusun dalam bentuk peta tematik. Luasan perairan yang layak bagi pengembangan budi daya laut dihasilkan setelah seluruh data parameter utama pembobotan dalam bentuk peta tematik di-overlay-kan (tumpang susunkan). Diagram alur analisis spasial penentuan lokasi pengembangan budi daya laut dapat dilihat pada Gambar 2.

Kriteria yang digunakan dalam penyusunan matrik kesesuaian dan pembobotan untuk penentuan kelayakan lahan budi daya laut mengacu pada kriteria yang telah disusun oleh beberapa peneliti di antaranya budi daya ikan dalam keramba jaring apung (Ahmad et al., 1995; Imanto et al., 1995; Ismail et al., 1998; Mayunar et al., 1995; dan Beveridge, 1996), budi daya rumput laut (Mubarak et al., 1990), dan budi daya mutiara (CMFRI, 1991; Winanto, 2004). Tabel 1 menyajikan matrik kesesuaian dan pembobotan data untuk penentuan kelayakan lahan budi daya laut.

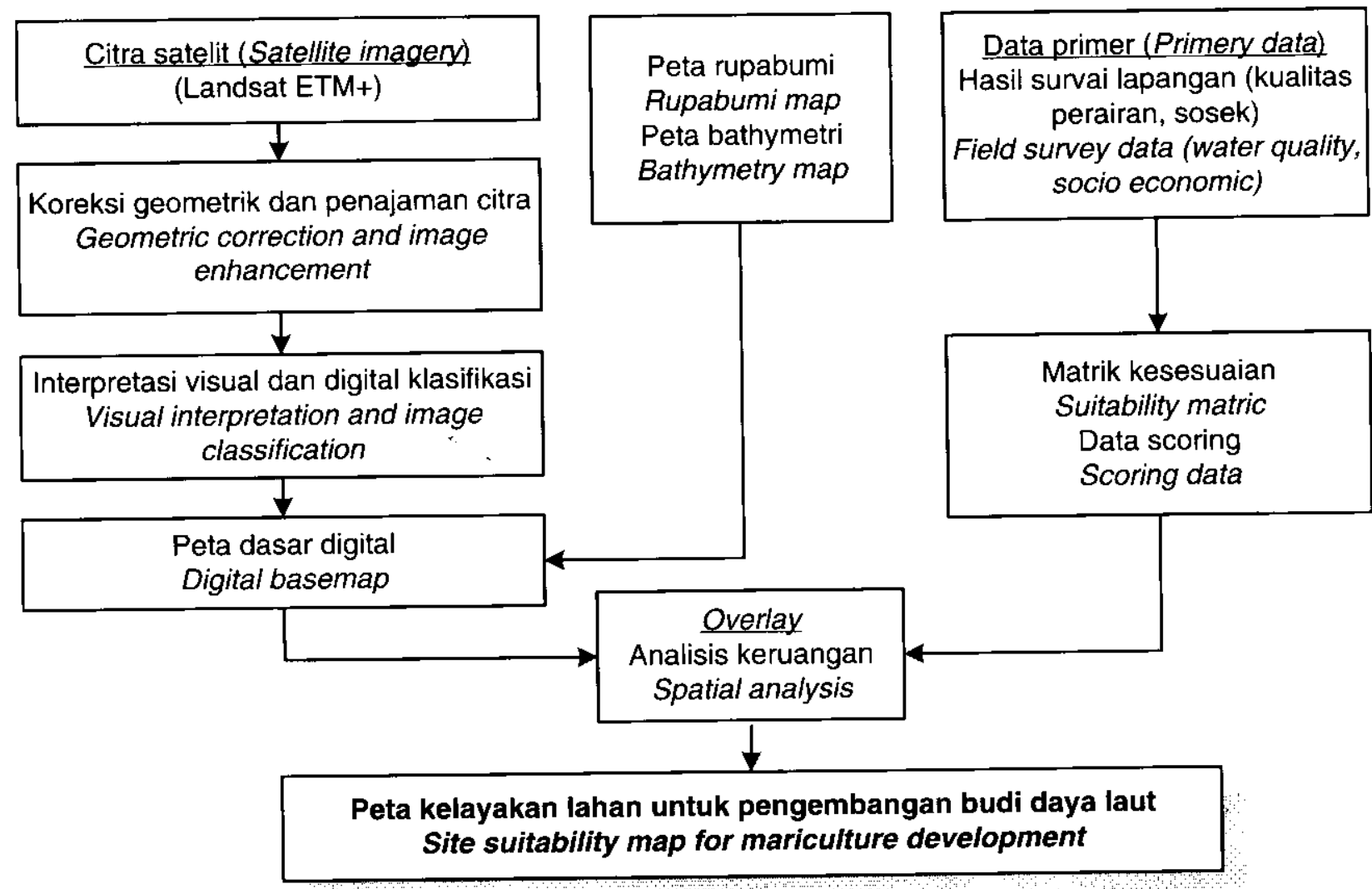

Gambar 2. Diagram alur penentuan lokasi pengembangan budi daya laut Figure 2. Flow chart of site selection method for mariculture development 
Analisis data dilakukan dengan cara overlay dari beberapa peta tematik yang diperlukan. Penilaian secara kuantitatif terhadap tingkat kelayakan lahan dilakukan melalui skoring dengan faktor pembobot. Parameter yang mempunyai pengaruh dominan dan relatif tidak dapat diubah memiliki faktor pembobot yang paling besar, sebaliknya parameter yang kurang dominan memiliki faktor pembobot yang lebin kecil. Lahan yang masuk kategori sangat layak (S1) memiliki nilai total 30 , kategori cukup layak (S2) memiliki nilai total 20 dan kategori tidak layak $(\mathrm{N})$ memiliki nilai total 10 . Analisis secara kuantitatif menggunakan pendekatan:

$$
Y=\sum a i . X n
$$

di mana:

$Y=$ nilai akhir

ai $=$ faktor pembobot

$X_{n}=$ nilai tingkat kesesuaian lahan

Untuk mendapatkan selang nilai pada setiap kategori ditentukan dari nilai persentase dari hasil perhitungan di atas. Dengan demikian akan diperoleh kisaran persentase setiap kategori sebagai berikut:

- Kategori sangat layak (S1) : $Y \geq 85 \%$

* Kategori layak (S2)

* Kategori tidak layak (N)

$$
: Y=50 \%-84 \%
$$$$
: Y \leq 50 \%
$$

\section{HASIL DAN BAHASAN}

\section{Kondisi Umum Perairan}

Dari hasil analisis citra satelit Landsat ETM+, diperoleh gambaran letak geografis lokasi survai membentang dari $121^{\circ} 30^{\prime}-121^{\circ} 46^{\prime}$ Bujur Timur dan $0^{\circ} 26^{\prime}-0^{\circ} 34^{\prime}$ Lintang Utara. Dengan memanfaatkan data inderaja ini beberapa ekosistem pesisir dapat dipetakan dan dihitung luasannya yaitu hutan bakau 2.500 ha dan terumbu karang 2.440 ha. Adanya pulaupulau kecil, di antaranya Pulau Puntu Daa, Puntu Kiki, Imam, Olinggobe, dan Banggo Daa yang terdapat di lokasi penelitian, sangat berguna sebagai penghalang gelombang yang menjadikan perairan ini relatif tenang dan terlindung dari ombak.

Pemilihan kombinasi band yang tepat dalam pengolahan data inderaja sangatlah penting. Dengan pilihan band yang sesuai maka akan menampilkan perbedaan spektral untuk setiap tutupan lahan dengan jelas baik di darat maupun di laut, sehingga nantinya akan mempermudah dalam melakukan pengelompokan spektral (image classification). Gambar 3 menampilkan lokasi penelitian dengan kombinasi band 543.

Kondisi oseanografi di Teluk Tomini sangat berpengaruh terhadap kondisi perairan di lokasi penelitian. Hal ini disebabkan lokasi penelitian masuk

Tabel 1. Matrik kesesuaian dan pembobotan data kualitas air pemilihan lokasi budi daya laut Table 1. Suitability matrik and weighting value of water quality data for mariculture site selection

\begin{tabular}{|c|c|c|c|c|c|}
\hline \multirow{2}{*}{ Parameter Parameters } & \multirow{2}{*}{$\begin{array}{c}\text { Satuan } \\
\text { Unit }\end{array}$} & \multirow{2}{*}{$\begin{array}{c}\text { Bobot } \\
\text { Weight (\%) }\end{array}$} & \multicolumn{3}{|c|}{ Nilai (Value) } \\
\hline & & & 30 & 20 & 10 \\
\hline Morfologi & & 20 & Terlindung & Cukup terlindung & Terbuka \\
\hline Morphology & & & Close & Moderately close & Open \\
\hline $\begin{array}{l}\text { Kedalaman } \\
\text { Kedalaman (Water denth) }\end{array}$ & m & 15 & $8-15$ & $16-25$ & $<8 \&>25$ \\
\hline & & & & & \\
\hline Arus (Water current) & $\mathrm{cm} / \mathrm{dt}$ & 10 & $5-15$ & $16-30$ & $<5 \&>30$ \\
\hline Substrat dasar & & 10 & Pasir dan pecahan karang & Pasir berlumpur & Lumpur \\
\hline Sediment & & & Sand and rubble & Sandy clay & Clay \\
\hline Kecerahan (Transparency) & $\mathrm{m}$ & 10 & $>3$ & $1-3$ & $<1$ \\
\hline Salinitas (Salinity) & ppt & 10 & $30-35$ & $20-29$ & $<20 \&>35$ \\
\hline Pencemar & & 10 & Tidak ada & Sedang & Tinggi \\
\hline Pollutan & & & Low & Moderat & High \\
\hline Keamanan & & 5 & Aman & Agak aman & Tidak aman \\
\hline Security & & & Good & Fair & Poor \\
\hline Keterjangkauan & & 5 & Mudah & Agak sulit & Sulit \\
\hline Accessibility & & & Good & Fair & Poor \\
\hline Tenaga Kerja & & 5 & Mudah & Agak sulit & Sulit \\
\hline Availability of labour & & & Good & Fair & Poor \\
\hline
\end{tabular}

\section{a. Keramba jaring apung (floating net cage culture)}


b. Budi daya rumput laut (seaweed culture)

\begin{tabular}{|c|c|c|c|c|c|}
\hline \multirow{2}{*}{$\begin{array}{l}\text { Parameter } \\
\text { Parameters }\end{array}$} & \multirow{2}{*}{$\begin{array}{c}\text { Satuan } \\
\text { Unit }\end{array}$} & \multirow{2}{*}{$\begin{array}{c}\text { Bobot } \\
\text { Weight (\%) }\end{array}$} & \multicolumn{3}{|c|}{ Nilai (Value) } \\
\hline & & & 30 & 20 & 10 \\
\hline Morfologi & & 15 & Terlindung & Cukup terlindung & Terbuka \\
\hline Morphology & & & Close & Moderately close & Open \\
\hline Kedalaman (Water depth) & m & 15 & $1--10$ & $11--15$ & $<1 \&>15$ \\
\hline Arus (Water current) & $\mathrm{cm} / \mathrm{dt}$ & 10 & $20--30$ & $31-40$ & $<20 \&>40$ \\
\hline Substrat dasar & & 10 & Pasir dan pecahan & Pasir berlumpur & Lumpur \\
\hline Sediment & & & Sand and rubble & Sandy clay & Clay \\
\hline Kecerahan (Transparency) & $\mathrm{m}$ & 10 & $>3$ & $1--3$ & $<1$ \\
\hline Salinitas (Salinity) & ppt & 10 & $32--34$ & $28--31$ & $<28 \&>34$ \\
\hline Hewan herbivore & & 5 & Tidak ada & Sedang & Tinggi \\
\hline Herbivor animal & & & Low & Moderat & High \\
\hline Pencemar & & 10 & Tidak ada & Sedang & Tinggi \\
\hline Pollutan & & & Low & Moderat & High \\
\hline Keamanan & & 5 & Aman & Agak aman & Tidak aman \\
\hline Security & & & Good & Fair & Poor \\
\hline Keterjangkauan & & 5 & Mudah & Agak sulit & Sulit \\
\hline Accessibility & & & Good & Fair & Poor \\
\hline Tenaga Kerja & & 5 & Mudah & Agak sulit & Sulit \\
\hline A vailability of labour & & & Good & Fair & Poor \\
\hline
\end{tabular}

\section{c. Budi daya kerang mutiara (pearl culture)}

\begin{tabular}{|c|c|c|c|c|c|}
\hline \multirow{2}{*}{$\begin{array}{l}\text { Parameter } \\
\text { Parameters }\end{array}$} & \multirow{2}{*}{$\begin{array}{c}\text { Satuan } \\
\text { Unit }\end{array}$} & \multirow{2}{*}{$\begin{array}{c}\text { Bobot } \\
\text { Weight (\%) }\end{array}$} & \multicolumn{3}{|c|}{ Nilai (Value) } \\
\hline & & & 30 & 20 & 10 \\
\hline Morfologi & & 10 & Terlindung & Cukup terlindung & Terbuka \\
\hline Morphology & & & Close & Moderately close & Open \\
\hline Kedalaman (Water depth) & m & 15 & $10--20$ & $21--30$ & $<10 \&>30$ \\
\hline Arus (Water current) & $\mathrm{cm} / \mathrm{dt}$ & 10 & $5--15$ & $16--30$ & $<5 \&>30$ \\
\hline Substrat dasar & & 10 & Batu kerikil & Pecahan karang dan pasir & lumpur \\
\hline Sediment & & & Gravelly & Rubble and sand & clay \\
\hline Kecerahan (Transparency) & $\mathrm{m}$ & 10 & $5 \geq 5$ & $1-4$ & $<1$ \\
\hline Salinitas (Salinity) & ppt & 10 & $24--38$ & $15--24$ & $<15 \&>38$ \\
\hline Kesuburan perairan* & & 10 & Banyak & Sedang & Sedikit \\
\hline Water fertility & & & High & Moderat & Low \\
\hline Pencemar & & 10 & Tidak ada & Sedang & Tinggi \\
\hline Pollutan & & & Low & Moderat & High \\
\hline Keamanan & & 5 & Aman & Agak aman & Tidak aman \\
\hline Secunity & & & Good & Fair & Poor \\
\hline Keterjangkauan & & 5 & Mudah & Agak sulit & Sulit \\
\hline Accessibility & & & Good & Fair & Poor \\
\hline Tenaga Kerja & & 5 & Mudah & Agak sulit & Sulit \\
\hline Availability of labour & & & Good & Fair & Poor \\
\hline
\end{tabular}

* berdasarkan jenis dan kelimpahan plankton (based on total species and abundance of plankton)

dalam kawasan Teluk Tomini. Kondisi pasang surut berdasarkan hasil pengamatan bulan Oktober 2003 oleh Supangat et al., 2003 dan Burhanuddin et al.,
2003 diperoleh bahwa tipe pasang surut (pasut) di perairan Teluk Tomini adalah campuran yang cenderung ke harian ganda dengan tinggi rata-rata air 


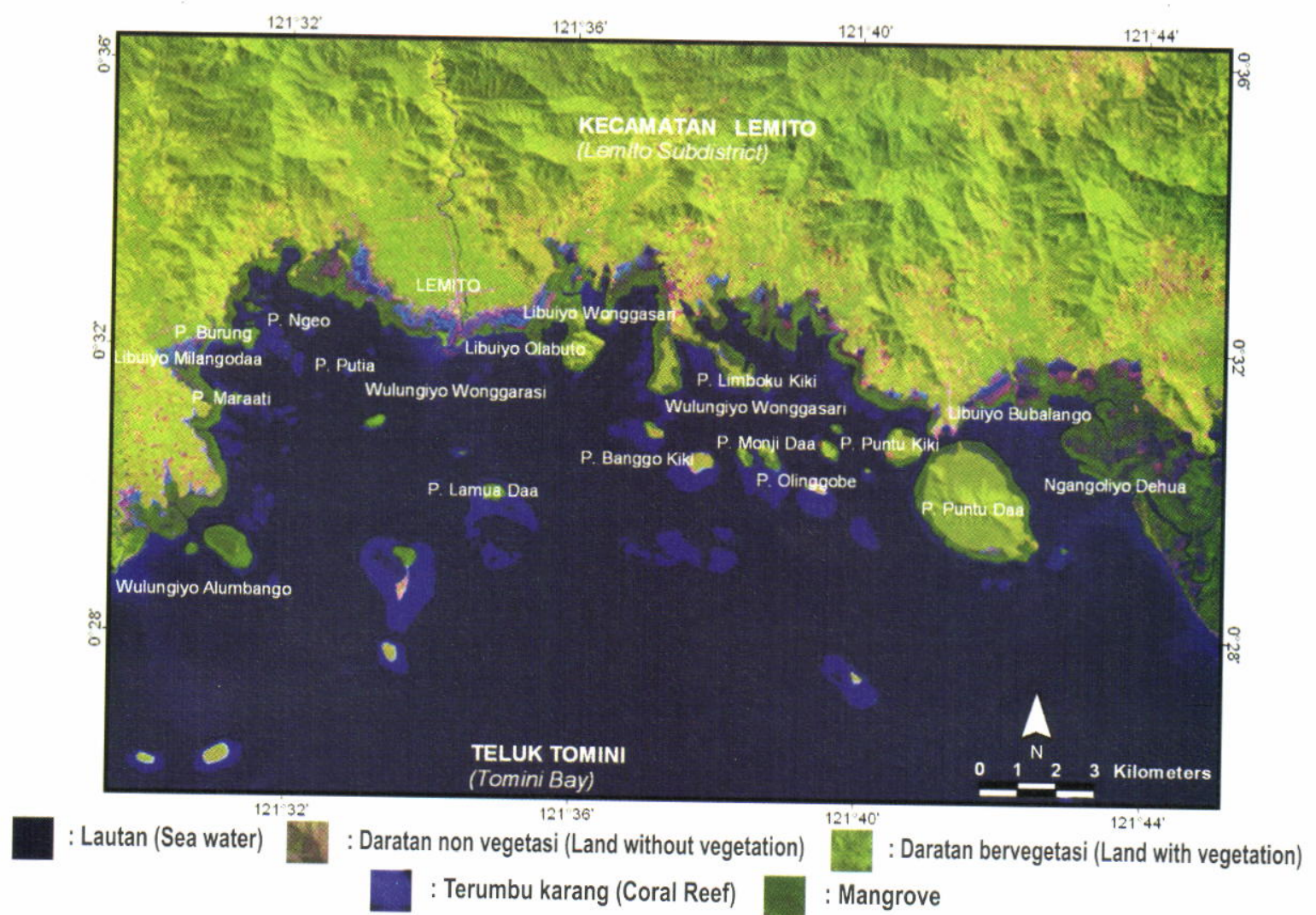

Gambar 3. Gambaran umum lokasi penelitian di perairan Lemito dengan Landsat ETM+ band 543 (RGB) akuisisi

Figure 3. General features of research location at Lemito waters using Landsat ETM+ band 543 (RGB) acquired
on $21 \mathrm{~J}$ une 2001

pasang tertinggi $+250 \mathrm{~cm}$ dan air surut terendah -264 $\mathrm{cm}$ dengan tunggang maksimum $514 \mathrm{~cm}$ (pengukuran dilakukan dengan patokan tinggi ratarata muka laut (MSL/mean sea level). Kondisi pasut ini sesuai dengan prediksi pasut di perairan Mountong yang merupakan stasiun pasut Dinas Hidro Oseanografi (Dinas Hidro Oseanografi, 2003) terletak di perbatasan antara Provinsi Sulawesi Tengah dengan Provinsi Gorontalo. Prediksi pasut untuk tiga hari pengamatan dapat dilihat pada Gambar 4.

\section{Kondisi Perairan}

Secara umum kualitas perairan permukaan terutama parameter fisik dan kimia di 39 titik pengamatan masih dalam batas toleransi untuk kegiatan budi daya laut. Perbedaan waktu sampling sangat berpengaruh pada beberapa parameter kualitas perairan. Data kisaran kualitas perairan parameter fisik dan kimia hasil pengukuran di lapangan disajikan pada Tabel 2.

Parameter fisik kualitas perairan di lokasi penelitian masih dalam kisaran yang baik untuk kegiatan budi daya perikanan. Suhu perairan dengan kisaran $29,7^{\circ} \mathrm{C}-31,8^{\circ} \mathrm{C}$ masih dalam kategori layak bagi kegiatan budi daya laut. Untuk budi daya ikan, suhu dengan kisaran $27^{\circ} \mathrm{C}-32^{\circ} \mathrm{C}$ merupakan kisaran yang baik dan layak (Mayunar et al., 1995). Kecerahan perairan hasil pengukuran menunjukkan masih dalam kisaran yang baik untuk budi daya biota laut yaitu $3 \mathrm{~m}$. Kecerahan perairan makin menurun pada daerah sebelah timur Pulau Puntu Daa (stasiun 34, 35, 37, dan 39). Hal ini disebabkan lokasi dekat dengan daerah pertambakan yang memiliki kedalaman perairan rendah, selain itu lokasi ini sedikit terbuka sehingga intensitas gelombang lebih besar dan arus perairan yang cukup kencang menyebabkan terjadinya pengadukan (Gambar 5). Tinggi gelombang dan kecepatan arus berdasarkan hasil pengukuran mempunyai kisaran nilai antara $0-80 \mathrm{~cm}$ dan $10-80 \mathrm{~cm} / \mathrm{dt}$, kisaran nilai tersebut masih dalam kategori yang baik untuk kegiatan budi daya.

Kedalaman perairan merupakan parameter penting lainnya yang perlu diperhatikan dalam menganalisis kelayakan lahan. Hasil penggabungan data kedalaman Dishidros dan pengukuran lapangan menunjukkan kisaran kedalaman 0,7-69 m (Gambar 5). Untuk kegiatan budi daya ikan dalam KJA, kedalaman optimal saat surut antara dasar keramba dengan dasar perairan adalah 4-5 m (Beveridge, 1996). Penelitian Rachmansyah (2003) di Teluk Awerange menunjukkan bahwa kedalaman perairan 
Pasang surut(14--16 Agustus 2003)

Tidal condition (14--16 August 2003)

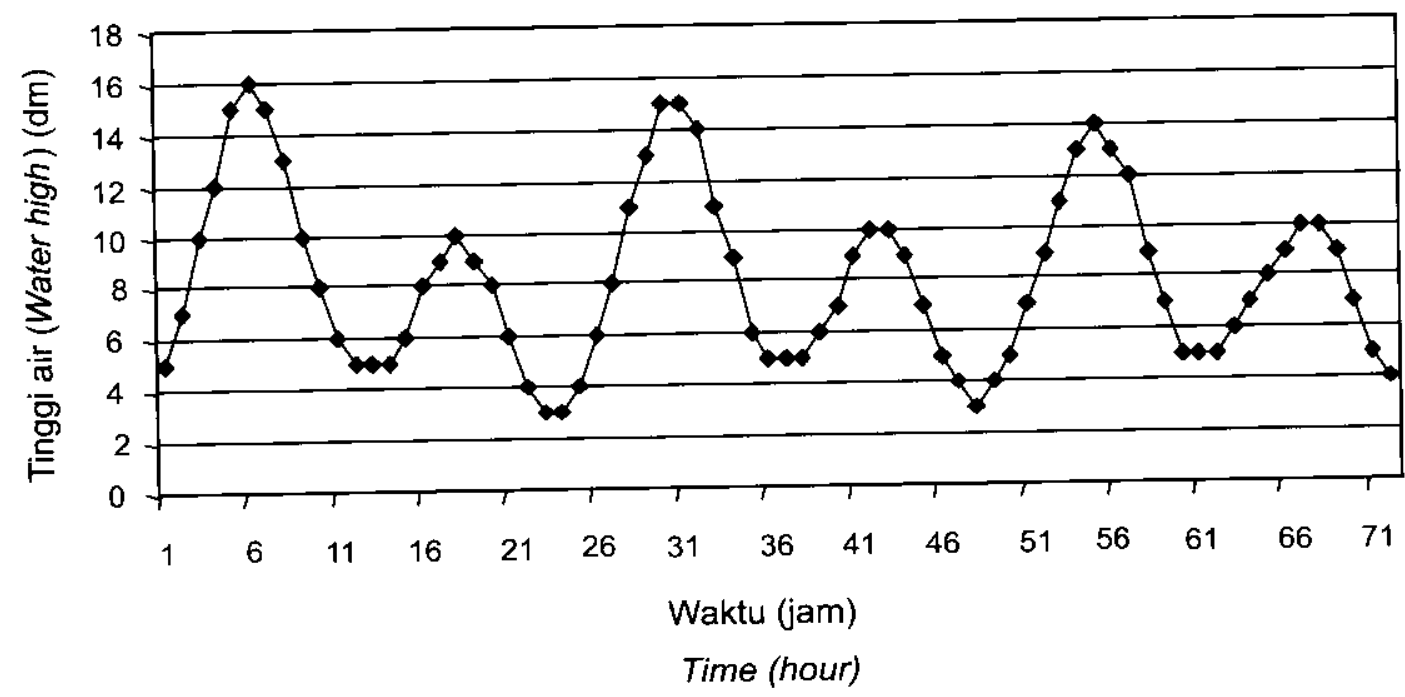

Gambar 4. Kondisi pasang surut stasiun perairan Mountong pada bulan Agustus 2003

Figure 4. Tidal condition at Mountong station on August 2003

Tabel2. Kisaran nilai kualitas air di perairan Lemito, Kabupaten Pohuwato

Table 2. Value range of water quality at Lemito waters, Pohuwato Regency

\begin{tabular}{lcc}
\hline \multicolumn{1}{c}{ Parameter (Parameters) } & Satuan (Unit) & Kisaran nilai (Value range) \\
\hline Fisik (Physical) & & \\
Kedalaman (Water depth) & $\mathrm{m}$ & $0.7--69(13.2 \pm 12.3)^{\star}$ \\
Suhu air (Temperature) & ${ }^{\circ} \mathrm{C}$ & $29.7--31.8(30.6 \pm 0.5)$ \\
Kecerahan (Transparency) & $\mathrm{m}$ & $0.6--11.5(5 \pm 3)$ \\
Tinggi gelombang (Wave height) & $\mathrm{cm}$ & $0--80(24.6 \pm 21.3)$ \\
Kecepatan arus (Water current) & $\mathrm{cm} / \mathrm{dt}$ & $10--80(40.7 \pm 22.6)$ \\
\hline Kimia (Chemical) & & \\
Salinitas (Salinity) & $\mathrm{ppt}$ & $24--31(26.6 \pm 1.8)$ \\
pH & & $8.30--8.86(8.62 \pm 0.08)$ \\
DO (Dissolve oxygen) & $\mathrm{mg} / \mathrm{L}$ & $4.36--8.00(6.37 \pm 0.83)$ \\
\hline
\end{tabular}

*) data lapangan dan data batimetri Dishidros, $N=385$ (field data and bathymetry data- Dishidros, $N=385$ )

- (rataan \pm simpangan baku) (average \pm standard deviation)

minimal di bawah keramba untuk pengembangan budi daya bandeng adalah $4,4 \mathrm{~m}$.

Parameter kimia hasil pengukuran lapangan umumnya masih dalam kategori yang baik untuk kegiatan budi daya biota laut. Salinitas perairan yang terukur berkisar antara $24-31 \mathrm{ppt}$. Kisaran salinitas ini masih dalam kategori yang layak bagi kegiatan budi daya laut. Kandungan oksigen terlarut (DO) dalam perairan sangat penting bagi sintasan hewan tersebut. Rendahnya DO akan berpengaruh terhadap tingkah laku biota budi daya. Untuk kegiatan budi daya kandungan DO yang disyaratkan adalah > $5 \mathrm{mg} / \mathrm{L}(\mathrm{KLH}, 2004)$. Dari hasil pengukuran menunjukkan bahwa DO berkisar antara $4,36-8,00$ $\mathrm{mg} / \mathrm{L}$, hal ini berarti masih dalam kisaran yang baik untuk kegiatan budi daya perikanan.

Parameter lain yang perlu mendapat perhatian adalah hasil analisis beberapa parameter kimia dan kandungan logam berat. Hasil analisis laboratorium untuk parameter kimia (fosfat, nitrat, nitrit, dan amoniak) dan logam berat ( $\mathrm{Cd}, \mathrm{Zn}, \mathrm{Pb}$, dan $\mathrm{Cu}$ ) di 10 titik pengamatan dapat dilihat pada Tabel 3 .hfghfgj

Parameter kimia hasil analisis laboratorium yang meliputi fosfat, nitrat, nitrit, dan amoniak memiliki kisaran nilai yang masih layak bagi kegiatan budi 
laut sesuai dengan yang disyaratkan dalam baku mutu lingkungan ( $\mathrm{KLH}, 2004)$.

Secara alamiah, unsur-unsur logam berat terdapat di mana-mana dalam konsentrasi sangat rendah. Konsentrasi tersebut akan meningkat sejalan dengan bertambahnya aktivitas manusia seperti: perindustrian, pertambangan dan pertanian serta limbah perkotaan dan buangan lainnya yang banyak mengandung logam. Merkuri $(\mathrm{Hg})$ merupakan jenis logam berat yang paling berbahaya diikuti dengan kadmium, seng, timbal, dan kromium (Clark, 1977 dalam Mayunar et al., 1995).

Konsentrasi logam berat di lokasi penelitian untuk timbal berkisar $0,013-0,066 \mathrm{mg} / \mathrm{L}$; cadmium $0,001-0,003 \mathrm{mg} / \mathrm{L}$; tembaga $0,004-0,007 \mathrm{mg} / \mathrm{L}$; dan seng $0,005-0,043 \mathrm{mg} / \mathrm{L}$; masih dalam kisaran baku mutu budi daya biota laut. Menurut KLH (2004) baku mutu timbal, cadmium, tembaga, dan seng masing-masing adalah $0,008 \mathrm{mg} / \mathrm{L} ; 0,001 \mathrm{mg} / \mathrm{L}$; $0,008 \mathrm{mg} / \mathrm{L}$; dan $0,05 \mathrm{mg} / \mathrm{L}$. Konsentrasi tertinggi logam berat umumnya ditemukan pada lokasi yang pada bagian daratannya terdapat pemukiman penduduk yaitu stasiun 1 dan 11 .

Pengambilan contoh tanah juga dilakukan untuk mengetahui kondisi tekstur tanah dasar perairan. Hasil analisis sedimen dasar menunjukkan: persentase pasir berkisar antara $0 \%-72 \%$, liat $5 \%-66 \%$, dan debu $6 \%-94 \%$. Hal ini menunjukkan bahwa jenis sedimen substrat dasar didominasi oleh lempung berpasir dan pasir. Data kondisi tekstur dasar perairan ini sangat erat kaitannya dengan (1) kemungkinan untuk penempatan KJA dan rancangan konstruksi KJA terutama untuk tipe jangkar yang akan dipakai, (2) kemudahan pemasangan fasilitas budi daya, (3) produktivitas perairan, dan (4) kekeruhan perairan dan sedimentasi. Sebaran spasial sedimen/pasir dapat dilihat pada Gambar 5 .

Bagi kegiatan budi daya kerang mutiara, kesuburan perairan merupakan faktor yang menjadi perhatian dalam penentuan kelayakan lahan. Kelimpahan plankton yang menandakan kesuburan perairan merupakan sumber makanan yang baik bagi kerang mutiara yang dibudidayakan, tetapi jika kelimpahan plankton sampai melebihi batas (blooming) harus dihindari karena mencirikan terjadinya pencemaran biologi. Hasil pengamatan menunjukkan jumlah jenis plankton berkisar $8-16$ jenis dan kelimpahan berkisar antara 16.069-126.646 ind./L. Kelimpahan plankton terbesar ditemukan di stasiun 27 dan 36 . Jenis plankton dominan di antaranya Chaetoceros, Acartia, Rhizosolenia, Bacteriastrum, dan Ceratium. Indeks keragaman dan indeks dominansi plankton adalah $0,79-1,18$ dan $0,07-0,18$.

Data kualitas air yang mempunyai pengaruh dominan dan relatif tidak mengalami perubahan yang cepat dilakukan interpolasi untuk mengetahui pola spasial dari data tersebut. Gambar 5 menampilkan beberapa data parameter fisik perairan hasil interpolasi.

Tabel 3.Konsentrasi kandungan kimia dan logam berat di perairan Lemito, Kabupaten Pohuwatu Table 3.Chemical and heavy metal consentrations at Lemito waters, Pohuwato Regency

\begin{tabular}{|c|c|c|c|c|c|c|c|c|}
\hline \multirow{2}{*}{$\begin{array}{l}\text { Stasiun } \\
\text { Station }\end{array}$} & \multicolumn{4}{|c|}{$\begin{array}{c}\text { Kimia (mg/L) } \\
\text { Chemical parameters }\end{array}$} & \multicolumn{4}{|c|}{$\begin{array}{c}\text { Logam berat (mg/L) } \\
\text { Heavy metal }\end{array}$} \\
\hline & $\begin{array}{c}\text { Fosfat } \\
\text { Phosphate }\end{array}$ & $\begin{array}{l}\text { Nitrit } \\
\text { Nitrite }\end{array}$ & $\begin{array}{l}\text { Nitrat } \\
\text { Nitrate }\end{array}$ & $\begin{array}{c}\text { Amonia } \\
\text { Ammonia }\end{array}$ & $\mathbf{P b}$ & Cd & $\mathrm{Cu}$ & $\mathbf{Z n}$ \\
\hline 1 & 0.023 & 0.108 & 0.019 & 0.058 & 0.066 & 0.002 & 0.004 & 0.018 \\
\hline 3 & 0.023 & 0.108 & 0.021 & 0.050 & 0.013 & 0.003 & 0.004 & 0.017 \\
\hline 9 & 0.023 & 0.105 & 0.019 & 0.062 & 0.013 & 0.002 & 0.004 & 0.005 \\
\hline 11 & 0.029 & 0.108 & 0.021 & 0.075 & 0.066 & 0.001 & 0.007 & 0.021 \\
\hline 15 & 0.041 & 0.129 & 0.021 & 0.058 & 0.013 & 0.001 & 0.004 & 0.011 \\
\hline 16 & 0.029 & 0.122 & 0.014 & 0.062 & 0.013 & 0.001 & 0.004 & 0.014 \\
\hline 17 & 0.029 & 0.115 & 0.014 & 0.058 & - & - & 0.004 & 0.007 \\
\hline 25 & 0.035 & 0.115 & 0.019 & 0.062 & 0.013 & 0.001 & - & 0.011 \\
\hline 27 & 0.035 & 0.122 & 0.019 & 0.075 & 0.026 & - & 0.004 & 0.004 \\
\hline 36 & 0.035 & 0.122 & 0.018 & 0.056 & 0.026 & - & 0.004 & 0.043 \\
\hline Rataan (Average) & 0.0302 & 0.1154 & 0.0185 & 0.0616 & 0.028 & 0.002 & 0.004 & 0.0151 \\
\hline $\begin{array}{l}\text { Simpangan baku } \\
\text { Standard deviation }\end{array}$ & 0.0062 & 0.0081 & 0.0026 & 0.0079 & 0.021 & 0.001 & 0.001 & 0.0113 \\
\hline
\end{tabular}




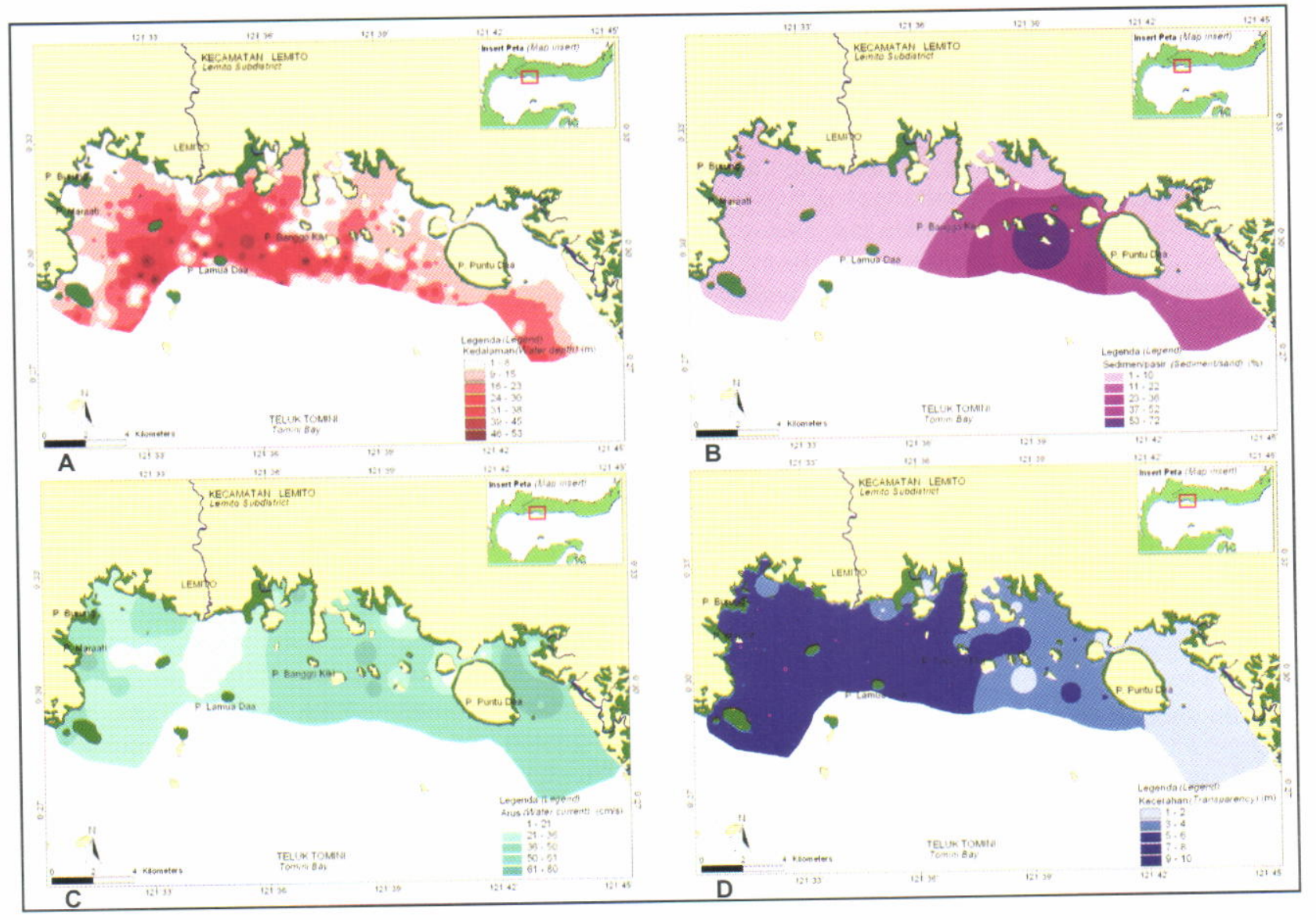

Gambar 5. Sebaran spasial kualitas perairan di perairan Lemito, Kabupaten Pohuwato: (a) kedalaman, (b) sedimen/pasir, (c) kecepatan arus, dan (d) kecerahan

Figure 5. Spatial distribution of water quality at Lemito waters, Pohuwato Regency: (a) water depth, (b) sediment/sand, (c) water current, and (d) transparency

Data yang perubahannya cukup dinamis (contohnya: suhu, salinitas, arus) dibuat hanya untuk mendapat-kan gambaran pola sebaran spasial pada saat pengambilan data tersebut, sehingga dapat membantu dalam menganalisis kelayakan lahan budi daya laut.

\section{Status Peruntukan Lahan}

Di sekitar perairan Lemito telah ditemukan adanya kegiatan budi daya laut yang meliputi: budi daya ikan, rumput laut, dan kerang mutiara. Gambar 6 menunjukkan peta lokasi kegiatan budi daya laut yang telah berkembang di perairan Lemito.

Keramba jaring apung yang ada, selain digunakan untuk kegiatan budi daya juga berfungsi sebagai penampung ikan-ikan karang ekonomis penting seperti kerapu, kakap merah, dan napoleon hasil tangkapan dari alam. Kegiatan budi daya makin dikembangkan sejalan dengan makin berkurangnya hasil tangkapan dari alam. Selain itu, kegiatan budi daya ikan dalam KJA di lokasi penelitian juga telah diperkenalkan oleh Pusat Riset Perikanan Budidaya pada tahun 2003. Melalui kerja sama antara Dinas
Kelautan dan Perikanan Provinsi dengan pengusaha budi daya setempat telah berhasil dibuat suatu demplot (percontohan) budi daya ikan kerapu dari jenis kerapu bebek dan macan (Gambar 7). Budi daya rumput laut yang berkembang di lokasi penelitian umumnya dilakukan oleh nelayan sekitar perairan dengan menggunakan metode long line. Jenis rumput laut yang dibudidayakan adalah Eucheuma sp. dan Gracillaria sp. Untuk budi daya mutiara, terdapat satu perusahaan yang telah menanamkan modalnya yaitu PT Maria Southsea Pearls Indonesia. Metode budi daya yang digunakan adalah long line (Gambar 7).

Sarana transportasi (aksesibilitas) memiliki peranan dan pengaruh yang penting dalam rangka pemilihan lokasi pengembangan budi daya laut (transportasi benih, produksi, dll.) di daerah ini. Umumnya jalan menuju lokasi sudah tersedia yaitu melalui trans Sulawesi yang dilanjutkan dengan jalan kabupaten dan desa. Jarak dari lokasi ke ibu kota provinsi sekitar $200 \mathrm{~km}$ yang dapat ditempuh selama $4-5$ jam dengan angkutan darat. Sedangkan jarak dari lokasi budi daya ke Bandar Udara Jalaludin, 


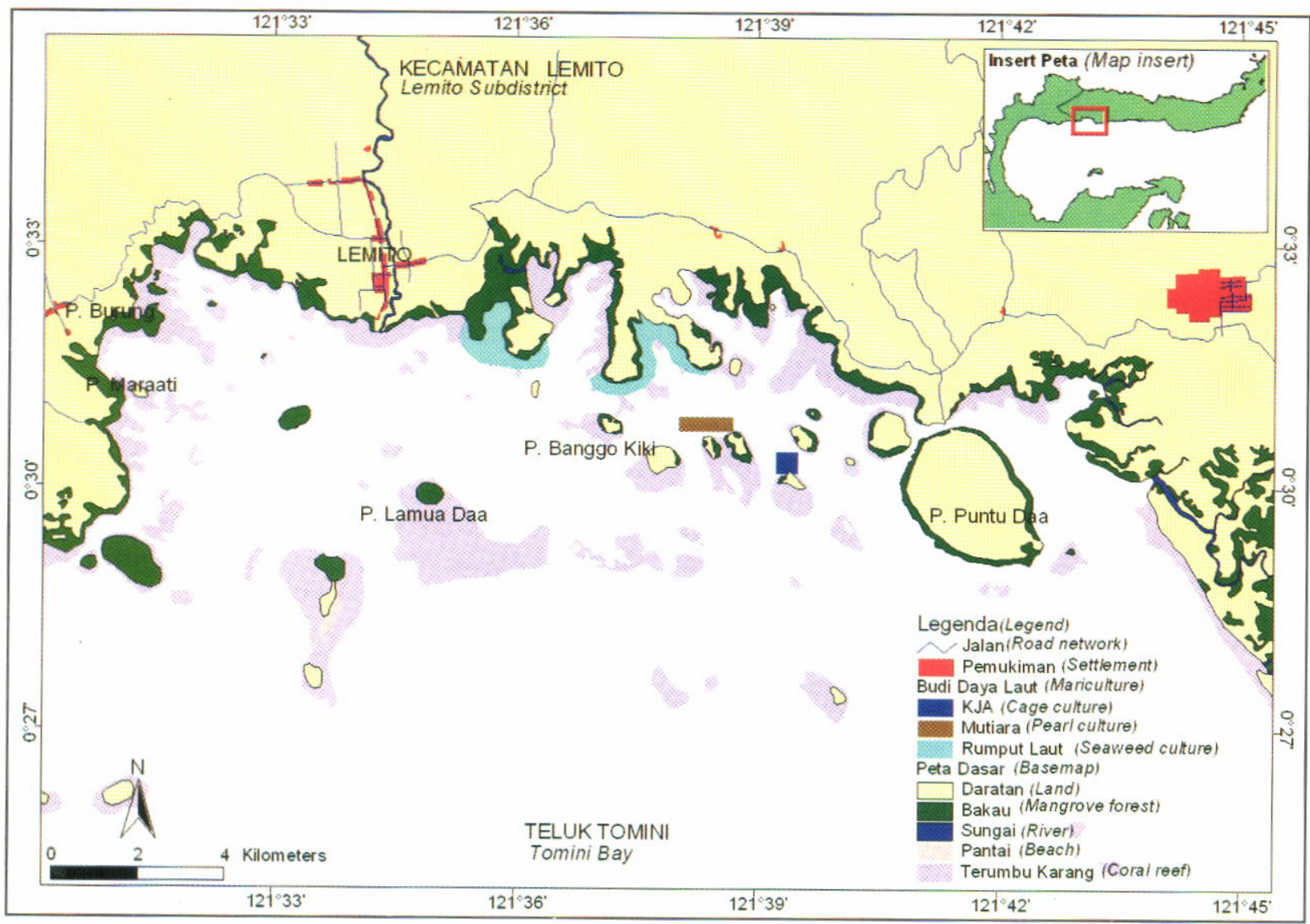

Gambar 6. Kegiatan budi daya laut yang sudah ada di lokasi penelitian Figure 6. Existing mariculture activities at research location

Provinsi Gorontalo dapat ditempuh sekitar 3-4 jam. Selain melalui darat, transportasi laut merupakan pilihan yang sangat efektif. Ikan budi daya yang telah dihasilkan selama ini dipasarkan melalui laut dengan cara pembeli datang langsung ke lokasi.

\section{Lokasi Pengembangan Budi Daya Laut}

Dari hasil scoring dan pembobotan data kualitas air serta didukung oleh berbagai pertimbangan sosial ekonomi serta pemanfaatan lahan bagi sektor lainnya, maka terwujud suatu peta tingkat kelayakan lahan bagi kegiatan budi daya laut. Peta tingkat kelayakan lahan yang ditampilkan hanya pada tingkat yang dapat dikembangkan (kategori sangat layak). Total luasan daerah penelitian di perairan Lemito mencapai 12.947 ha, memiliki lahan pengembangan kawasan budi daya yang sangat layak untuk KJA seluas 342 ha atau hanya sebesar $3 \%$ dari total luasan lokasi penelitian,

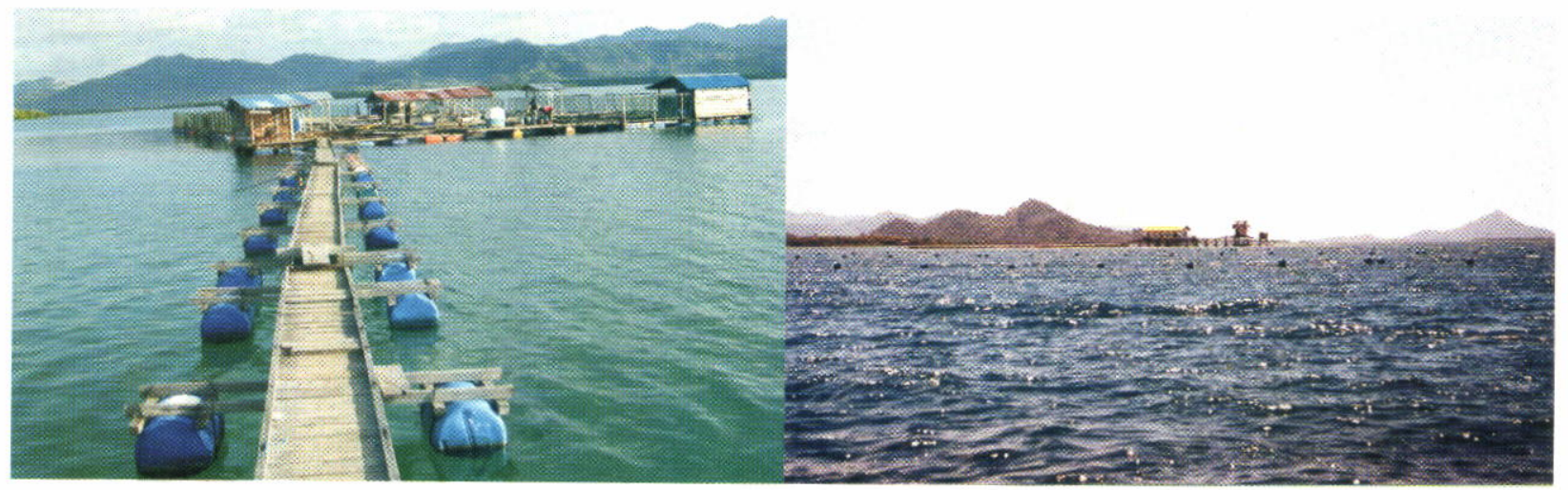

Gambar 7. Aktivitas budi daya laut yang ada di Lemito, Kabupaten Pohuwato Figure 7. Mariculture activities present at Lemito, Pohuwato Regency 
untuk budi daya rumput laut seluas 1.005 ha atau hanya sebesar $8 \%$ dari total luasan lokasi penelitian, dan untuk budi daya kerang mutiara seluas 233 ha atau hanya sebesar $2 \%$ dari total luasan lokasi penelitian. Peta tematik kelayakan lahan budi daya laut dapat dilihat pada Gambar 8.

Budi daya laut (ikan) jika tidak dilaksanakan dengan prinsip sustainability akan menjadi sumber pencemaran dan tidak dapat berjalan lama. Penggunaan pakan secara intensif yang menghasilkan sisa-sisa pakan, dan kotoran akan menyebabkan terjadinya penyuburan perairan (eutrofikasi) yang pada gilirannya menyebabkan rendahnya kadar oksigen, sehingga dapat menyebabkan kematian pada ikan. Untuk pengembangan usaha yang berkelanjutan, maka potensi yang ada sekiranya tidak dimanfaatkan seluruhnya tetapi harus disediakan area yang fungsinya sebagai penyangga.

Untuk budi daya ikan dalam KJA, jika 1 unit keramba terdiri atas 4 keramba dengan ukuran $2 \times 2$ $\times 2 \mathrm{~m}^{3}$ maka 1 ha lahan pengembangan budi daya dapat dimanfaatkan sebanyak 60 unit keramba. Hal ini berarti pemanfaatannya hanya $10 \%$ dari lahan yang dapat dikembangkan (Hanafi et al., 2001). Dengan luasan lahan pengembangan budi daya sebesar 342 ha maka jumlah keramba yang dapat dioperasionalkan adalah mencapai 20.520 unit KJA. Kepadatan tebar ikan yang disarankan menurut APEC/ SEAFDEC (2001) adalah 15-20 ekor/m³. Kepadatan yang lebih tidak disarankan karena ikan mudah stres dan terserang penyakit.

Menurut Mubarak et al. (1990), pemanfaatan lahan pengembangan budi daya rumput laut tergantung dari metode yang digunakan. Jika metode rakit long line yang digunakan maka 1 ha lahan dapat dimanfaatkan secara efektif untuk 20 unit usaha menggunakan ukuran 2,5 $\times 5 \mathrm{~m}^{2}$. Namun apabila metode lepas dasar yang digunakan maka 1 ha lahan dapat dimanfaatkan secara efektif untuk 60 unit usaha menggunakan ukuran $10 \times 10 \mathrm{~m}^{2}$. Dengan luasan lahan pengembangan budi daya rumput laut sebesar 1.005 ha maka jumlah rakit/long line yang dapat dioperasionalkan mencapai 20.100 unit.

Untuk budi daya kerang mutiara, jika pemanfaatannya hanya $10 \%$ dari lokasi yang layak, maka luasan area yang dapat dimanfaatkan adalah seluas 23 ha. Metode budi daya yang dapat digunakan

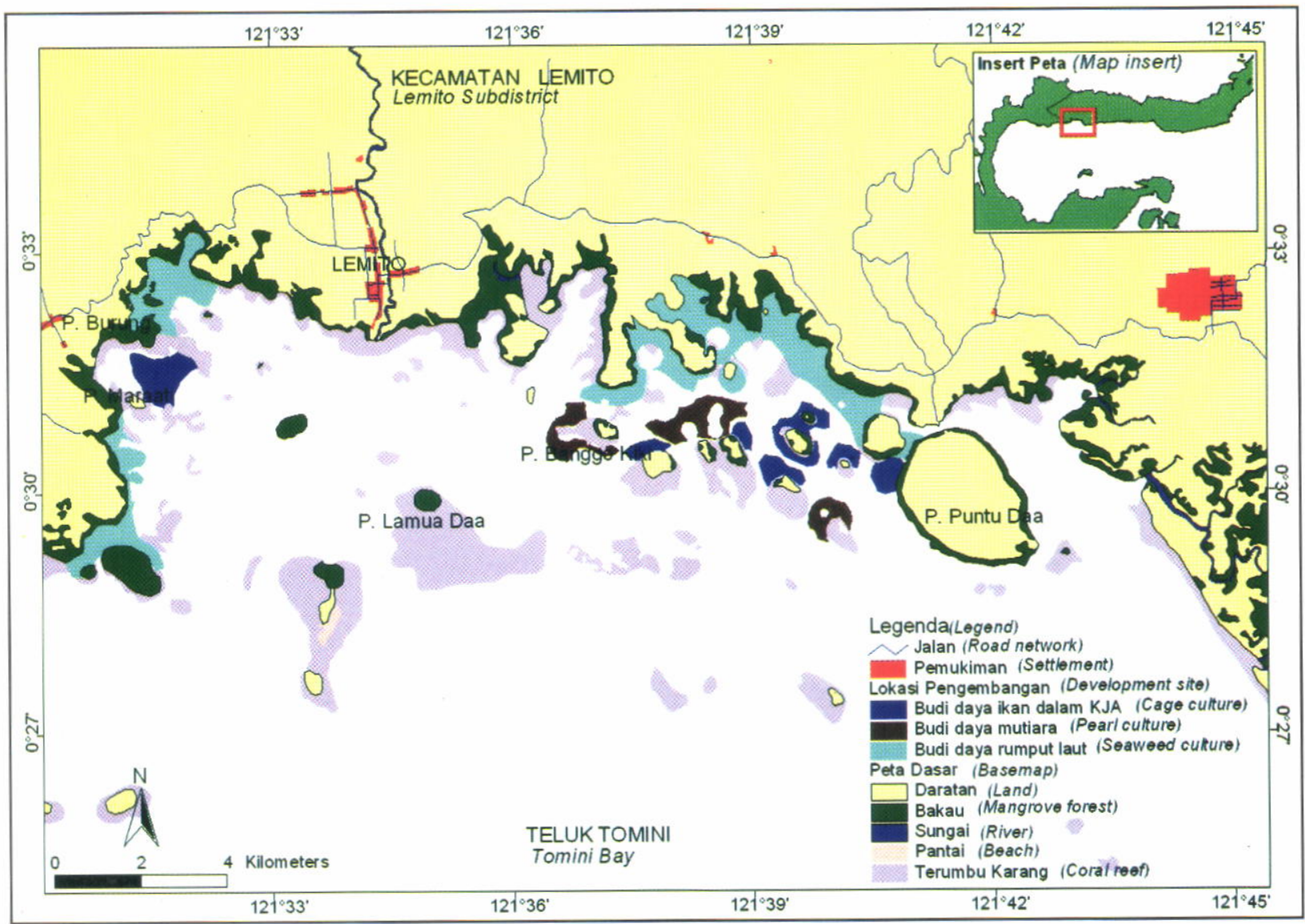

Gambar 8. Peta kelayakan lahan budi daya laut di perairan Lemito

Figure 8. Area suitability map for mariculture at Lemito waters 
adalah long line atau rakit. Perbedaan kedua metode ini menurut CMFRI (1991), adalah berdasarkan morfologi lokasi. Metode rakit digunakan pada lokasi yang cukup terlindung sedangkan untuk lokasi yang agak terbuka penggunaan metode long line lebih sesuai. Ukuran rakit yang biasa digunakan adalah 6 $\times 5 \mathrm{~m}^{2}$

\section{KESIMPULAN DAN SARAN}

Perairan Lemito yang termasuk dalam kawasan Teluk Tomini merupakan aset pemerintah daerah setempat untuk mengembangkan kegiatan perikanan budi daya. Hal ini didukung dengan kondisi perairan yang masih baik serta banyaknya pulau-pulau kecil di sekitar perairan yang menjadikan tempat ini sangat cocok bagi kegiatan budi daya laut.

Hasil pengukuran kualitas perairan yang meliputi: parameter fisik, kimia, kualitas substrat, dan konsentrasi logam berat serta dipadukan dengan data inderaja (Landsat ETM+) menunjukkan perairan ini masih mempunyai daya dukung yang dapat dimanfaatkan untuk kegiatan budi daya laut. Analisis SIG melalui pembobotan, skoring dan overlay menunjukkan area dengan luas total 12.947 ha mempunyai lahan pengembangan kawasan budi daya yang sangat layak untuk KJA seluas 342 ha. Jika 1 ha lahan dapat dimanfaatkan untuk 60 unit ( 1 unit $=4$ keramba) keramba dengan ukuran $2 \times 2 \times 2 \mathrm{~m}^{3}$ maka lahan tersebut dapat dimanfaatkan sebanyak 20.520 unit keramba. Untuk kegiatan budi daya rumput laut dengan luasan lahan pengembangan sebesar 1.005 ha maka jumlah rakit/long line yang dapat dioperasionalkan mencapai 20.100 unit. Untuk budi daya kerang mutiara memiliki luasan pengembangan sebesar 233 ha.

Di lokasi penelitian terdapat beberapa lokasi yang telah dimanfaatkan untuk pengembangan usaha di antaranya kegiatan budi daya rumput laut yang dilakukan oleh masyarakat sekitar, budi daya ikan yang dilakukan oleh pengusaha, dan budi daya kerang mutiara oleh PT Maria Southsea Pearls Indonesia.

\section{UCAPAN TERIMA KASIH}

Pada kesempatan ini penulis mengucapkan terima kasih kepada semua anggota tim dari Pusat Riset Perikanan Budidaya yang telah membantu pelaksanaan penelitian ini dan Bapak Suryadi yang telah memberikan fasilitas selama pelaksanaan penelitian di lapangan.

\section{DAFTAR PUSTAKA}

Ahmad, T., A. Rukyani, dan A. Wijono. 1995. Teknik budi daya laut dengan keramba jaring apung. Dalam
Sudradjat et al. (eds.). Prosiding Temu Usaha Pemasyarakatan Teknologi Keramba Jaring Apung bagi Budi Daya Laut. Puslitbang Perikanan, p. 69--87.

Anonim. 2002a. Rencana Tata Ruang Wilayah Provinsi Gorontalo 2002-2016, Buku I: Fakta dan Analisis. Bappeda, $185 \mathrm{pp}$.

Anonim. 2002b. Rencana Tata Ruang Wilayah Kabupaten Boalemo 2002-2012. Bappeda Kabupaten Boalemo, $104 \mathrm{pp}$.

APECISEAFDEC. 2001. Pembudidayaan dan Managemen Kesehatan Ikan Kerapu. APEC, Singapore dan SEAFDEC, Iloilo, Philippines, $95 \mathrm{pp}$.

Beveridge, M.C.M. 1996. CageAqua-culture (Eds. $2^{\text {nd }}$ ). Fishing News Books LTD. Farnham, Surrey, England, $352 \mathrm{pp}$.

Burrough, P.A. and R.A. McDonnel. 1998. Principle of Geographical Information Systems. Oxford University Press, 327 pp.

Burhanuddin, S., A. Supangat, B. Sulistiyo, T. Rameyo, dan C.R. Kepel. 2003. Profil Sumber Daya Keluatan dan Perikanan Teluk Tomini. Badan Riset Kelautan dan Perikanan. Departemen Kelautan dan Perikanan, $84 \mathrm{pp}$.

Central Marine Fisheries Research Institute (CMFRI). 1991. Pearl Oyster Farming and Pearl Culture. Training Manual on Pearl Oyster Farming and Pearl Culture in India, FAO Training Manual No. 8. Regional Sea farming Development and Demonstration Project (RAS/90/002). http://www.fao.org/docrep/field/ 003/AB726E/AB726E00.htm\#TOC [Juni 2004].

Clark, W.A.V. and P.L. Hosking. 1986. Statistical Methods for Geographers. John Wiley \& Sons, Inc, 513 pp.

Dinas Hidro Oseanografi. 2003. Daftar Pasang Surut Kepulauan Indonesia. Jakarta, 637 pp.

Hanafi, A., Tarunamulia, A. Rachman, dan T. Ahmad. 2001. Penataan ruang Teluk Pegametan di Kecamatan Gerokgak, Bali untuk pengembangan sea farming. Dalam Sudradjat et al. (ed.) Teknologi Budi Daya Laut dan Pengembangan Sea Farming di Indonesia. Puslitbang Eksplorasi Laut dan Perikanan, p. 57-69.

Imanto, P.T., N. Listyanto, dan B. Priono. 1995. Desain dan kontruksi keramba jaring apung untuk budi daya ikan laut. Dalam Sudradjat et al. (ed.). Prosiding Temu Usaha Pemasyarakatan Teknologi Keramba Jaring Apung bagi Budi daya Laut. Puslitbang Perikanan, Badan Litbang Pertanian, p. 216-230.

Ismail, W., S.E. Wardoyo, dan B. Priono. 1998. Lokasilokasi potensial bagi panti benih terapung ikan karang di selatan P. Bintan dan Karimun Jawa. J. Pen. Per. Indonesia, IV (1): 36-46.

Ismail, W., E. Pratiwi, Wedjatmiko, E. Savitri, Suwidah, dan A. Wijono. 2002. Analisis Kebijakan Pengembangan Usaha Budi Daya Laut. Dalam Heruwati et al. (eds.) Analisis Kebijakan Pembangunan Perikanan. Pusat Riset Pengolahan Produk dan Sosial Ekonomi Kelautan dan Perikanan, p. $1-20$.

Kapetsky, J.M., L. McGregor, and H. Nanne. 1987. A geographical information system and satellite remote 
sensing to plan for aquaculture development: A FAO - UNEP/GRID Cooperative Study in Costal Rica. FAO Fish. Tech. Pap., 287: $51 \mathrm{pp}$

KLH. 2004. Keputusan Menteri Negara Lingkungan Hidup No. 51 tahun 2004, tanggal 8 April 2004 tentang Baku Mutu Air Laut. Kementerian Lingkungan Hidup, Jakarta, $11 \mathrm{pp}$.

Morain, S. 1999. GIS Solution in Natural Resource Management: Balancing the Technical-Political Equation. On Word Press. USA, $361 \mathrm{pp}$.

Mayunar, R. Purba, dan P.T. Imanto. 1995. Pemilihan lokasi untuk usaha budidaya ikan laut. Dalam Sudradjat et al. (eds.). Prosiding Temu Usaha Pemasyarakatan Teknologi Keramba Jaring Apung bagi Budidaya Laut. Puslitbang Perikanan, Badan Litbang Pertanian, p. 179-189.

Mubarak, H., S. Ilyas, W. Ismail, I.S. Wahyuni, S.H. Hartati, E. Pratiwi, Z. Jangkaru, dan R. Arifuddin. 1990. Petunjuk Teknis Budidaya Rumput Laut. Pusat Penelitian dan Pengembangan Perikanan, PHP/KAN/ PT/13/1990, Jakarta, 93 pp.

Perez, O.M., T.C. Telfer, and L.G. Ross. 2003. Use of GISbased models for integrating and developing marine fish cages within the tourism industry in tenerife (Canary Island). Coastal Management, 31: 355-366.
PKSPL IPB. 2002. Album Peta Penyusunan Pra Analisis Penggunaan Tata Ruang Pesisir dan Pualu-Pulau Kecil Provinsi Gorontalo, 30 pp.

Rachmansyah, R. Dahuri, R.F. Kaswadji, D.G. Bengen, dan D. Soedharma. 2003. Pendugaan Daya Dukung Perairan Teluk Awerange untuk Pengembangan Budidaya Bandeng dalam Keramba Jaring Apung. Program Studi Pengelolaan Sumberdaya Pesisir dan Lautan, Institut Pertanian Bogor, 20 pp.

Ramelan, S.H. 1998. Pengembangan Budi Daya Ikan Laut di Indonesia. Dalam Sudradjat et al. (eds.). Prosiding Seminar Teknologi Perikanan Pantai, 6-7 Agustus 1998. Puslitbang Perikanan, p. 59-79.

Saefudin, S. Budiyono, N. Yustiningsih, I.R. Astuti, dan U. Idawati. 1996. Potensi Pengembangan Perikanan Tambak di Teluk Banten. Pelatihan Sistem Informasi Geografis dan Inderaja Tingkat Perencana. Jakarta, $30 \mathrm{pp}$.

Supangat, A., T. Wagey, dan S. Burhanuddin, 2003. Daya Dukung Kelautan dan Perikanan Selat Sunda, Teluk Tomini, Teluk Saleh, dan Teluk Ekas. Tim Proyek Carrying Capacity Badan Riset Kelautan dan Perikanan, $122 \mathrm{pp}$.

Winanto, T. 2004. Memproduksi Benih Tiram Mutiara. Penebar Swadaya, Seri Agribisnis, 96 pp. 